Nedžad Leko

UDK 811.163.4'367

Nermina Čordalija

DOI: 10.4312/linguistica.56.1.173-191

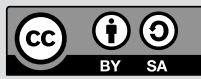

Ivana Jovović

Nevenka Marijanović

Lidija Perković

Dženana Telalagić

Amra Bešić

Midhat Šaljić

University of Sarajevo*

\title{
STRATEGIES OF PARTICIPLE AGREEMENT WITH CONJOINED SUBJECTS IN BOSNIAN/CROATIAN/SERBIAN
}

\section{INTRODUCTION}

In Bosnian/Croatian/Serbian (BCS), the agreement forms of the participle in the predicate may be realised in three different ways when the subject consists of conjoined noun phrases depending on the phi features of these noun phrases. The participle may agree in number and gender with the conjoined subject phrase as a whole (agreement with the maximal projection, i.e. projection of the conjunction (\&) as the head of a conjoined phrase $(\& \mathrm{P})$ ), or it may agree with the hierarchically highest noun phrase $\left(\mathrm{NP}_{1}\right)$, or it may agree with the noun phrase closest to the participle $\left(\mathrm{NP}_{2}\right)$, as represented in (1) for the conjoined phrase nagrade i priznanja 'awards and recognitions':

(1)

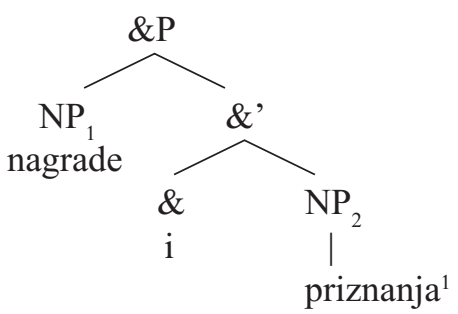

The experimental research we present in this paper demonstrates that the participle may be realised in three different forms, as in the following examples, which illustrate participle agreement forms when the subject consists of conjoined plural noun phrases of different genders [Feminine + Neuter]:

* nedzad.leko@ff.unsa.ba

1 We assume that conjoined NPs have a hierarchical structure, as presented in (1). However, it should be pointed out that other opinions can be found in the literature - there are assumptions that the configuration of these phrases is linear (flat) (see Culicover and Jackendoff 2005: 143) even in narrow syntax. 


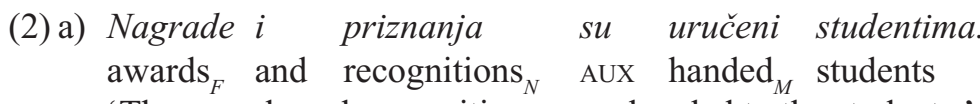
'The awards and recognitions were handed to the students.'

b) Nagrade i priznanja

su uručena studentima. $\operatorname{handed}_{N}$

c) Nagrade i priznanja

su uručene studentima. handed $_{F}$

The masculine form (uručeni) in (2a) illustrates agreement with the maximal projection $(\& \mathrm{P})$ in (1), which is a projection of the conjunction $\&(i)$ as the head of a conjoined phrase. The conjoined phrase (\&P) is masculine in gender by default, and consequently, the participle in (2a) does not agree either with $\mathrm{NP}_{1}$ or $\mathrm{NP}_{2}$, but rather with the maximal projection (\&P). The neuter form (uručena) in (2b) illustrates agreement with $\mathrm{NP}_{2}$ (priznanja), which is closest to the participle. Finally, the feminine form in (2c) illustrates agreement with $\mathrm{NP}_{1}$ (nagrade), which is hierarchically in the highest position in this conjoined phrase.

These data point to the existence of three distinct strategies of subject-predicate agreement when the subject consists of conjoined noun phrases. Gender and number agreement forms of participles in the predicate may be computed in three different ways, depending on the features of conjoined noun phrases in the subject. Participles may agree in gender and number with the subject phrase as a whole (that is agreement with the maximal projection - a Boolean Phrase (\&P)), or with the conjunct which is closest to the participle, or with the conjunct which is hierarchically the highest conjunct. We demonstrate in this paper that, in this respect, BCS behaves like Slovenian, which also has three strategies of agreement, as outlined by Marušič et al. (2015).

In order to test the initial hypothesis that there are three agreement strategies, we conducted a controlled experimental study of the morphosyntax of agreement between conjoined subjects and participles in BCS involving oral and written production experiments. The first experiment was a computer-assisted oral experiment in which the participants in the experiment were given first a test sentence like Poklon je uručen na pozornici 'The present was handed at the stage', and then conjoined noun phrases like nagrade i priznanja 'awards and recognitions'. Their task was to insert this phrase in the sentence instead of the noun poklon 'present', which would involve changing the participle agreement form. Both word orders were tested - the subject preceding the predicate (SV order), as in the previous example, and the opposite order (VS), as in $\mathrm{Na}$ pozornici je uručen poklon. The second experiment was a written experiment, which was conducted after the oral one. The written test contained exactly the same material as the oral experiment, with the same distribution of sentences, and the same participants were involved in both the oral and the written experiments.

The experiments revealed a high presence of default, masculine agreement and closest conjunct agreement. 50\% of preverbal conjoined phrases elicited the default 
masculine agreement, and $95 \%$ of postverbal conjoined phrases elicited the closest conjunct agreement. However, the relatively high percentage of participle forms agreeing with the first conjunct of the preverbal conjoined phrase confirmed that highest conjunct agreement (HCA) is a legitimate agreement strategy in BCS. On the other hand, a very small number of participle forms agreeing with the last conjunct of the postverbal conjoined phrase confirmed that last conjunct agreement (LCA) in postverbal contexts cannot be recognised as a separate agreement strategy. Instead, such examples should be characterised as performance errors. These results are contrary to Bošković's findings (2009), in which he does not acknowledge HCA as a legitimate strategy, however, our results do confirm the findings of Marušič et al. (2015).

The paper is organised as follows. In section 2 , we briefly discuss previous accounts of predicate agreement with conjoined subject noun phrases; in section 3, we present the experimental methodology; in section 4 , we discuss agreement with uniform gender conjuncts; in section 5 , we provide a detailed analysis of agreement with mixed gender conjuncts; in section 6 , we discuss our findings, summarising the main results.

\section{PREVIOUS ACCOUNTS}

The type of predicate agreement with conjoined subject noun phrases has been intensively studied both theoretically and experimentally, and, particularly in Slavic languages, it has received special attention. These studies can certainly contribute to a wider theoretical discussion about the role of agreement in grammar (this is discussed, for example, by Benmamoun et al. (2010), Munn (1999), Bhatt and Walkow (2013)), as well as to experimental investigations about attraction phenomena (as discussed, for example, by Bock and Miller (1991), Franck et al. (2006, 2007), and Franck (2011)). The investigations of agreement phenomena in Slavic languages are dominated by two approaches. One approach is exclusively syntactic, in which the syntactic analysis of agreement phenomena is based on native speaker intuitions or theoretical predictions (this kind of approach is taken by Bošković (2009) and Puškar and Murphy (2015)). The second approach, on the other hand, may be characterised as multi-component, arguing that in addition to the syntactic component, agreement processing involves also another component (phonetic) at the level of Phonetic Form (PF); this kind of approach is taken by Marušič et al. $(2007,2015)$.

\subsection{Bošković (2009)}

Bošković (2009) offers a uniform account of first and last conjunct agreement based on the operation Agree. According to Bošković, with postverbal subjects, participles in Serbo-Croatian always exhibit first conjunct agreement (for gender), and with preverbal subjects, only last conjunct agreement (for gender) is exhibited. His basic assumption is that the agreement is handled exclusively in the syntax by the operation Agree. In his analysis, Bošković proposes that the probe that is responsible for participial agreement searches for a goal to value its number and gender features. Since Conjunction Phrase $(\& \mathrm{P})$ is specified only for number, the probe finds disjoint valuators, \&P for number 
and the first conjunct for gender. This happens in cases of first conjunct agreement (with postverbal subjects). Bošković claims that the probe is a single probe (as opposed to approaches which argue for separate probes).

However, in the (abstract) structure which leads to last conjunct agreement, the Part (participle) probes for phi features, matching \& $\mathrm{P}$ for number and $\mathrm{NP}_{1}$ (the first conjunct) for gender. Since Part has an EPP feature, a phrase must move to SpecPartP. However, the problem is that there are two valuators, one requiring pied-piping of \&P and the other requiring pied-piping of $\mathrm{NP}_{1}$. Since both $\& \mathrm{P}$ and $\mathrm{NP}_{1}$ are in principle pied-pipable in Serbo-Croatian (this language allows Left Branch Extraction (LBE) condition violation), Bošković suggests that this kind of ambiguity prevents pied-piping, and consequently the valuation itself is blocked. The participial probe then initiates a second probing operation within a larger search space that includes $\mathrm{NP}_{2}$ (the second conjunct). The second conjunct can value the gender feature of the probe, and since it is in principle immobile, it is not a candidate for movement. Consequently, a valuator that undergoes pied-piping can be unambiguously determined. The Agree operation is then followed by movement of \&P to SpecPartP. This happens in the case of last conjunct agreement with preverbal subjects.

\subsection{Marušič et al. (2015)}

In their paper The Grammars of Conjunction Agreement in Slovenian (2015), Marušič, Nevins, and Badecker document three agreement strategies in Slovenian after conducting five experimental studies. The agreement can target one of the three feature-bearing controllers: Conj ${ }_{1}, \mathrm{Conj}_{2}$, or BoolP. Consequently, the locality criterion does not only mean the choice between the hierarchically highest or the linearly closest conjunct. It can also mean agreement with the closest phrase (XP) of the relevant type (BoolP). The factor that affects the gender feature computation process is that masculine is an unmarked gender in Slovenian (as in BCS).

In one of the grammars of agreement in Slovenian that they describe, operation Agree targets the BoolP and does not probe at the individual conjuncts. Since in their view, a Conj head cannot compute its own gender value, what we have is the default insertion of the masculine value into phi features on the participle.

In another grammar of agreement, Agree targets the BoolP first. However, as it finds no gender value, rather than inserting the default masculine values, it continues to probe within the BoolP. Which conjunct is the source for the gender feature is a matter of locality: it is either the hierarchically highest or the linearly closest conjunct. The process of linearisation whereby the BoolP structure is flattened affects the choice here. If the Agree-Copy operation takes place before conjunct flattening, the hierarchically closest conjunct is the gender agreement controller. However, if Agree-Copy takes place after the BoolP structure has been flattened, the linearly closest conjunct is selected by the Probe.

Marušič et al. (2015) assume that operation Agree is carried out in two steps: Agree-Link and Agree-Copy. Agree-Link always applies in narrow syntax, but AgreeCopy can apply either in syntax or post-syntactically, and the authors additionally 
assume that its order of application can vary with respect to linearisation (i.e. flattening of BoolP).

\section{METHODOLOGY AND OVERVIEW OF THE EXPERIMENTS}

As described in the Introduction, we demonstrate that BCS, like Slovenian, has three distinct strategies of subject-predicate agreement when the subject consists of conjoined noun phrases. Gender and number agreement forms of participles in the predicate may be computed in three different ways, depending on the features of conjoined noun phrases in the subject. Participles may agree in gender and number with the subject phrase as a whole (it is agreement with the maximal projection - a Boolean Phrase), or with the conjunct which is closest to the participle, or with the conjunct which is hierarchically the highest conjunct.

In order to prove this claim, we performed a controlled experimental study of the morphosyntax of agreement between conjoined subjects and participles in BCS. The experiments were conducted at the University of Sarajevo as a part of the EMSS project (Experimental Morphosyntax of South Slavic Languages, Leverhulme Trust/University College London). We conducted two types of studies: oral elicitation and written elicitation, and in both we registered variability in production elicited.

Both experiments - oral elicitation immediately followed by written elicitation were administered as part of a single session to the same group of participants. All participants in the experiments were students at the University of Sarajevo who are native speakers of BCS from Sarajevo. There were 30 participants: all third-year students at the University of Sarajevo who had finished primary and secondary school in Sarajevo or the immediate region.

The first experiment was a computer-assisted oral experiment. Participants were recorded and prompted by a computer screen to continue to the next sentence. The experiment was administered individually using the online software Ibex (Drummond 2011). It involved a self-paced reading and sentence-completion task. Participants read a model sentence appearing on the screen. They then saw a replacement noun phrase and were asked to replace the subject of the model sentence with this new noun phrase. Responses were recorded using Audacity and coded afterwards according to their agreement features.

The experimental design involved six examples for each of the following nine gender combinations of plural conjuncts: [Masc + Masc], $[\mathrm{Fem}+\mathrm{Fem}]$, [Neut + Neut $]$, $[$ Masc + Fem], [Masc + Neut], [Fem + Masc], [Fem + Neut], [Neut + Masc], and [Neut + Fem]. Additionally, the experimental material involved fillers. There were three filler conditions: paucal (numerals 2, 3,4) with a head noun in masculine singular, a hybrid noun $^{2}$ in feminine singular, and an object relative clause with a head noun in neuter

2 Hybrid nouns denote a plurality but have the form of a singular noun, e.g., djeca 'children', braća 'brothers', etc. (see Corbett 1983a, 1991). They trigger plural agreement on the predicate:
(i) Djeca/ braća plaču.
children $F . S G /$ brothers $F . S G$ cry $3 P L$ 
singular. There were 54 fillers, which means there were 108 stimuli in total for each participant.

In the first experiment, there were two sessions for each participant. In the first session, participants were tested on agreement forms of the predicate with a subject containing conjoined nouns preceding the predicate. In the second session, the subject followed the predicate. These sessions were recorded over 15 days.

The second experiment was a written experiment conducted using a fill-in-theblank questionnaire containing the same material as the oral experiment. Each example contained a model sentence and a stimulus - a conjoined phrase. Participants were instructed to write the form of the participle they felt was most appropriate with the conjoined phrase. As with the oral production experiment, the written experiment did not impose any time limits and was administered immediately after the oral experiment to the same participants who had participated in the oral experiment.

Nine sets of examples (illustrating nine conditions), each containing six sentences, plus 54 fillers, were presented. In the first session, the sentences contained a conjoined subject preceding the predicate, and in the second session, the order was reversed. This means that each participant was presented with 108 sentences in total.

Although we recognise that spoken language can better reflect native-speaker intuitions about language than can written language, as it does not allow for reflection on the correctness of an utterance, we conducted the written experiment to provide additional and clearer insight into agreement in BCS. We were aware of the fact that after being exposed to the examples in the oral experiment, the participants had already processed them when they encountered them for the second time in the written session. However, the written experiment was expected to contain fewer performance errors, since it gave the participants the possibility to skip examples or go back to them several times, which was not possible in the oral experiment.

There was a total of 6480 tokens resulting from nine lexicalisations of six conditions in two experiments (written and oral) and two sessions (pre-verbal vs. post-verbal placement of the conjoined subjects), completed by a total of 30 participants. However, the number of tokens actually considered in the analysis was 6074 , as presented in Table 1 in the Appendix. Participants skipped some examples or provided unclear answers, so such examples were not taken into consideration. This means that for each condition (e.g., two masculine pre-verbal subjects in written elicitation), there were 180 tokens in total.

We present the results of our experiments documenting the existence of three distinct grammars of conjunct agreement in BCS: agreement with the highest conjunct, agreement with the closest conjunct, or agreement with the Boolean Phrase itself.

\section{UNIFORM GENDER CONJUNCTS}

We first investigated possible patterns of participial agreement with uniform gender conjuncts when both conjuncts are plural, and when uniform gender plural subjects occur both preverbally and postverbally. Such subjects largely elicit participial agreement 
that corresponds to the gender of the two conjuncts. However, default masculine agreement occurs even when both conjuncts are feminine, or neuter, demonstrating that the 'resolution rule' of masculine agreement is attested even in uniform gender conjunctions (Corbett 1983a). However, this was registered predominantly in oral elicitation (44 examples oral, vs. 11 examples written).

\subsection{Preverbal Subjects}

In oral elicitation, 24 examples (or 13.71\%) of masculine default agreement were registered when both conjuncts were feminine, while only one example $(0.56 \%)$ was registered in written elicitation, as in (3): ${ }^{3}$

(3) Fotografije iskice su prijavljeni na konkurs. photos $_{F}$ and sketches ${ }_{F}$ AUX registered ${ }_{M}$ for competition

'Photographs and sketches were registered for the competition.'

In oral elicitation, 16 examples $(8.89 \%)$ of masculine default agreement were registered when both conjuncts were neuter, as in (4):

(4) Poglavlja i uputstva su predani na čitanje. chapters $_{N}$ and instructions ${ }_{N}$ AUX submitted for reading 'Chapters and instructions were submitted for reading.'

There were five examples (2.79\%) of masculine default agreement in written elicitation when both conjuncts were neuter.

Table 1: Numbers of participle agreement forms with uniform gender conjuncts with preverbal subjects

\begin{tabular}{|l|l|l|l|l|l|l|}
\cline { 2 - 7 } \multicolumn{1}{c|}{} & \multicolumn{3}{c|}{ WRITTEN } & \multicolumn{3}{c|}{ ORAL } \\
\cline { 2 - 7 } \multicolumn{1}{c|}{} & $\mathbf{M}$ & $\mathbf{F}$ & $\mathbf{N}$ & $\mathbf{M}$ & $\mathbf{F}$ & $\mathbf{N}$ \\
\hline $\mathbf{M}+\mathbf{M}$ & 179 & 0 & 0 & 178 & 0 & 0 \\
\hline $\mathbf{F}+\mathbf{F}$ & 1 & 179 & 0 & 24 & 151 & 0 \\
\hline $\mathbf{N}+\mathbf{N}$ & 5 & 0 & 174 & 16 & 0 & 164 \\
\hline
\end{tabular}

3 It should be emphasised that all examples contained only inanimate subject NPs.

4 When the example was produced more than once, the number in parenthesis after the example indicates how many times that example was produced, e.g. the example in (3) was produced six times. 


\subsection{Postverbal Subjects}

In postverbal elicitation, only nine examples of default masculine agreement were registered with the same gender conjuncts, all of them with feminine conjuncts, and these were almost equally distributed between oral (2.26\%) and written elicitation (3.16\%). Four examples were registered in oral elicitation, as in (5):

(5) Krajolikom su dominirali planine i rijeke.

Landscape AUX dominated ${ }_{M}$ mountains $_{F}$ and rivers $_{F}$

'Mountains and rivers dominated the landscape.'

Five examples were registered in written elicitation.

Table 2: Numbers of participle agreement forms with uniform gender conjuncts with postverbal subjects

\begin{tabular}{|l|l|l|l|l|l|l|}
\cline { 2 - 7 } \multicolumn{1}{c|}{} & \multicolumn{3}{c|}{ WRITTEN } & \multicolumn{3}{c|}{ ORAL } \\
\cline { 2 - 8 } \multicolumn{1}{c|}{} & $\mathbf{M}$ & $\mathbf{F}$ & $\mathbf{N}$ & $\mathbf{M}$ & $\mathbf{F}$ & $\mathbf{N}$ \\
\hline $\mathbf{M}+\mathbf{M}$ & 180 & 0 & 0 & 180 & 0 & 0 \\
\hline $\mathbf{F}+\mathbf{F}$ & 5 & 153 & 0 & 4 & 173 & 0 \\
\hline $\mathbf{N}+\mathbf{N}$ & 0 & 1 & 176 & 0 & 1 & 175 \\
\hline
\end{tabular}

\section{MIXED GENDER CONJUNCTS}

\subsection{Preverbal Subjects}

In written and oral elicitation with [Masc + Fem] plural conjuncts, both masculine and feminine agreement was present, but there were more examples of masculine agreement in written elicitation $(150$ examples $=83.80 \%)$ than in oral elicitation $(128=$ $73.56 \%$ ), whereas there were more feminine agreement forms in oral elicitation (45 examples $=25.86 \%)$ than in written elicitation $(27=15.08 \%)$. To summarise, the tendency for closest conjunct agreement (feminine) was more prominent in the oral than in the written experiments, although in both experiements, the masculine form of the participle was clearly dominant.

In written and oral elicitation with [Masc + Neut] plural conjuncts, both masculine and neuter agreement was present, but there were more examples of masculine agreement in the written elicitation (121 examples $=67.98 \%)$ than in oral elicitation $(95=54.60 \%)$, whereas there were more neuter agreement forms in the oral elicitation $(78$ examples $=44.83 \%)$ than in the written elicitation $(57=32.02 \%)$. Again, the tendency for closest conjunct agreement (neuter) was more prominent in the oral than in the written experiments, although in both experiments, the masculine form of the participle was dominant. 
Table 3: Numbers of participle agreement forms with mixed gender $(\mathrm{M}+\mathrm{F}$ and $\mathrm{M}+\mathrm{N})$ conjuncts: preverbal subjects

\begin{tabular}{|l|l|l|l|l|l|l|}
\cline { 2 - 7 } \multicolumn{1}{c|}{} & \multicolumn{3}{c|}{ WRITTEN } & \multicolumn{3}{c|}{ ORAL } \\
\cline { 2 - 7 } \multicolumn{1}{c|}{} & $\mathbf{M}$ & $\mathbf{F}$ & $\mathbf{N}$ & $\mathbf{M}$ & $\mathbf{F}$ & $\mathbf{N}$ \\
\hline $\mathbf{M}+\mathbf{F}$ & 150 & 27 & 2 & 128 & 45 & 1 \\
\hline $\mathbf{M}+\mathbf{N}$ & 121 & 0 & 57 & 95 & 1 & 78 \\
\hline
\end{tabular}

In written and oral elicitation with [Fem + Masc] plural conjuncts, almost all examples with masculine agreement forms were elicited and with almost equal distribution in both the written $(145$ examples $=93.55 \%)$ and the oral elicitation $(151=95.57 \%)$. However, there were 14 examples, nine $(5.81 \%)$ in the written and five $(3.16 \%)$ in the oral experiments, with feminine agreement, as in (6):

(6) Sedrilice i gliseri su uplovile u zaliv.

(6x) (written) sailboats $_{F}$ and speedboats ${ }_{M}$ AUX sailed $_{F}$ in bay

'Sailboats and speedboats sailed in the bay.'

Examples such as those in (6) contradict the claim by Bošković (2009) that highest conjunct agreement (HCA) in the preverbal position is not possible in BSC.

In written elicitation with [Fem + Neut] plural conjuncts, one half of elicited forms were default masculine (78 examples Masc (50\%) vs. 58 Neut (37.18\%). However, a considerable number of highest conjunct agreement forms (feminine) was recorded (20 examples $=12.82 \%$ ), as in (7):

(7) Nagrade i priznanja su uručene na pozornici.

prizes $_{F}$ and awards AUX presented $_{F}$ on stage

'Prizes and awards were presented on the stage.'

In oral elicitation with [Fem + Neut] plural conjuncts, the majority of elicited forms were neuter agreement forms (87 examples Neut (53.37\%) vs. 71 examples Masc $(43.56 \%))$. However, a small number of highest conjunct agreement forms (feminine) was recorded ( 5 examples $=3.07 \%)$.

Table 4: Numbers of participle agreement forms with mixed gender $(\mathrm{F}+\mathrm{M}$ and $\mathrm{F}+\mathrm{N})$ conjuncts: preverbal subjects

\begin{tabular}{|l|l|l|l|l|l|l|}
\cline { 2 - 7 } \multicolumn{1}{c|}{} & \multicolumn{3}{c|}{ WRITTEN } & \multicolumn{3}{c|}{ ORAL } \\
\cline { 2 - 7 } \multicolumn{1}{c|}{} & $\mathbf{M}$ & $\mathbf{F}$ & $\mathbf{N}$ & $\mathbf{M}$ & $\mathbf{F}$ & $\mathbf{N}$ \\
\hline $\mathbf{F}+\mathbf{M}$ & 145 & 9 & 1 & 151 & 5 & 2 \\
\hline $\mathbf{F}+\mathbf{N}$ & 78 & 20 & 58 & 71 & 5 & 87 \\
\hline
\end{tabular}


In written elicitation with [Neut + Masc] plural conjuncts, there were eight examples (5.23\%) of highest conjunct agreement (neuter), as in (8), and all others were masculine $(145$ examples $=94.77 \%)$.

(8) Pitanja i problemi

su napisana na tablu. questions $_{N}$ and problems ${ }_{M}$ AUX written $_{N}$ on board 'Questions and problems were written on the board.'

In oral elicitation with [Neut + Masc] plural conjuncts, there were eleven examples $(7.19 \%)$ of highest conjunct agreement (neuter), while others were masculine (141 examples $=92.16 \%$ ).

In written elicitation with [Neut + Fem] plural conjuncts, all three agreement forms were recorded, and the same applies to oral elicitation. In written elicitation, the dominant forms were default masculine (96 examples $=54.55 \%$ ); there were also 58 examples of feminine agreement (32.95\%) and 22 examples $(12.50 \%)$ of highest conjunct agreement (neuter), as in (9):

(9) Platna i skulpture su nestala u selidbi. canvases $_{N}$ and sculptures AUX disappeared $_{N}$ in removal 'Canvases and sculptures were lost during removal.'

In oral elicitation with [Neut + Fem] plural conjuncts, the dominant forms were masculine ( 82 examples $=51.25 \%$ ); there were 57 examples $(35.63 \%)$ of feminine agreement and 21 examples (13.13\%) of highest conjunct agreement (neuter).

Table 5: Numbers of participle agreement forms with mixed gender $(\mathrm{N}+\mathrm{M}$ and $\mathrm{N}+\mathrm{F})$ conjuncts: preverbal subjects

\begin{tabular}{|l|l|l|l|l|l|l|}
\cline { 2 - 7 } \multicolumn{1}{c|}{} & \multicolumn{3}{c|}{ WRITTEN } & \multicolumn{3}{c|}{ ORAL } \\
\cline { 2 - 7 } \multicolumn{1}{c|}{} & $\mathbf{M}$ & $\mathbf{F}$ & $\mathbf{N}$ & $\mathbf{M}$ & $\mathbf{F}$ & $\mathbf{N}$ \\
\hline $\mathbf{N}+\mathbf{M}$ & 145 & 0 & 8 & 141 & 1 & 11 \\
\hline $\mathbf{N}+\mathbf{F}$ & 96 & 58 & 22 & 82 & 57 & 21 \\
\hline
\end{tabular}

\subsection{Postverbal Subjects}

In written and oral elicitation with [Masc + Fem] plural conjuncts, only masculine agreement forms were elicited, with one exception in oral elicitation: a neuter agreement form, which is clearly a performance error. Similar results were obtained in written and oral elicitation with [Masc + Neut] plural conjuncts. In addition to masculine agreement forms, we recorded two examples with neuter participle forms in oral elicitation and three examples in written elicitation, as in (10): 
(10) Na tržište su dospjela mirisovi i sjenila.

(2x) (oral)

to market AUX reached ${ }_{N}$ perfumes $_{M}$ and eyeshadows ${ }_{N}$

'Perfumes and eyeshadows reached the market.'

Table 6: Numbers of participle agreement forms with mixed gender $(\mathrm{M}+\mathrm{F}$ and $\mathrm{M}+\mathrm{N})$ conjuncts: postverbal subjects

\begin{tabular}{|l|l|l|l|l|l|l|}
\cline { 2 - 7 } \multicolumn{1}{c|}{} & \multicolumn{3}{c|}{ WRITTEN } & \multicolumn{3}{c|}{ ORAL } \\
\cline { 2 - 8 } \multicolumn{1}{c|}{} & $\mathbf{M}$ & $\mathbf{F}$ & $\mathbf{N}$ & $\mathbf{M}$ & $\mathbf{F}$ & $\mathbf{N}$ \\
\hline $\mathbf{M}+\mathbf{F}$ & 177 & 0 & 0 & 179 & 0 & 1 \\
\hline $\mathbf{M}+\mathbf{N}$ & 173 & 0 & 3 & 173 & 0 & 2 \\
\hline
\end{tabular}

In written elicitation with [Fem + Masc] plural conjuncts, most forms were feminine $(135$ examples $\mathrm{Fem}=88.82 \%$ vs. $15 \mathrm{Masc}=9.87 \%)$. In oral elicitation, there were 141 feminine forms (92.76\%) and 11 examples of masculine forms (7.24\%), as in (11):

(11)

U roku su položeni vježbe i seminari.

(3x written, $1 \mathrm{x}$ oral) in time AUX passed $_{M}$ exercises $_{F}$ and seminars ${ }_{M}$ 'Exercises and seminars were passed on time.'

In written elicitation with [Fem + Neut] plural conjuncts, almost all forms were feminine. There were four examples $(2.50 \%)$ of masculine (default) agreement in written elicitation and six examples (3.82\%) in oral elicitation, as in (12):

(12)

Udućan su stigli olovke i rumenila.

(oral)

in shop AUX delivered ${ }_{M}$ pencils $_{F}$ and blushers ${ }_{N}$

'Pencils and blushers were delivered to the shop.'

In oral elicitation with [Fem + Neut] plural conjuncts, there were four neuter forms $(2.55 \%)$, as in (13):

(13) Na petak su pomaknuta sjednice i vijeća.

to Friday AUX rescheduled ${ }_{N}$ meetings $_{F}$ and assemblies ${ }_{N}$

'Meetings and assemblies were rescheduled for Friday.'

Table 7: Numbers of participle agreement forms with mixed gender $(\mathrm{F}+\mathrm{M}$ and $\mathrm{F}+\mathrm{N})$ conjuncts: postverbal subjects

\begin{tabular}{|l|l|l|l|l|l|l|}
\cline { 2 - 7 } \multicolumn{1}{c|}{} & \multicolumn{3}{c|}{ WRITTEN } & \multicolumn{3}{c|}{ ORAL } \\
\cline { 2 - 8 } \multicolumn{1}{c|}{} & $\mathbf{M}$ & $\mathbf{F}$ & $\mathbf{N}$ & $\mathbf{M}$ & $\mathbf{F}$ & $\mathbf{N}$ \\
\hline $\mathbf{F}+\mathbf{M}$ & 15 & 135 & 2 & 11 & 141 & 0 \\
\hline $\mathbf{F}+\mathbf{N}$ & 4 & 156 & 0 & 6 & 147 & 4 \\
\hline
\end{tabular}


In written and oral elicitation with [Neut + Masc] plural conjuncts, only four masculine forms were registered - one $(0.68 \%)$ in written and three $(2.03 \%)$ in oral elicitation, as in (14):
U vožnji su pomogli
upozorenja i savjeti.
(2x) (oral) in driving AUX assisted ${ }_{M}$ warnings $_{N}$ and suggestions ${ }_{M}$ 'Warnings and suggestions helped during ride.'

In written and oral elicitation with [Neut $+\mathrm{Fem}]$ plural conjuncts, most forms were neuter. There were nine examples with default masculine forms - three (1.68\%) in written and six (3.45\%) in oral elicitation, as in (15):
U sobu su naručeni jaja i salate.
(written and oral)
to room AUX ordered ${ }_{M} \operatorname{eggs}_{N}$ and salads
'Eggs and salads were ordered to the room.'

However, there were ten feminine forms: four examples (2.23\%) in written and six $(3.45 \%)$ in oral elicitation, as in (16):
Pred zoru su utihnule
nevremena i poplave.
(5x) (oral)
before dawn AUX subsided storms $_{N}$ and floods $F$
'Storms and floods subsided before dawn.'

Table 8: Numbers of participle agreement forms with mixed gender $(\mathrm{N}+\mathrm{M}$ and $\mathrm{N}+\mathrm{F})$ conjuncts: postverbal subjects

\begin{tabular}{|l|l|l|l|l|l|l|}
\cline { 2 - 7 } \multicolumn{1}{c|}{} & \multicolumn{3}{c|}{ WRITTEN } & \multicolumn{3}{c|}{ ORAL } \\
\cline { 2 - 8 } \multicolumn{1}{c|}{} & M & $\mathbf{F}$ & $\mathbf{N}$ & $\mathbf{M}$ & $\mathbf{F}$ & $\mathbf{N}$ \\
\hline $\mathbf{N}+\mathbf{M}$ & 1 & 0 & 145 & 3 & 0 & 145 \\
\hline $\mathbf{N}+\mathbf{F}$ & 3 & 4 & 172 & 6 & 6 & 162 \\
\hline
\end{tabular}

We will now discuss the examples of apparent agreement with the farthest conjunct in postverbal experiments. There were four such examples in the written experiments, all involving a neuter participle form with conjoined masculine and neuter plural nouns. Following the claim by Marušič et al. (2015) that a postverbal conjunction does not allow agreement with the second/ last/farthest conjunct, we treated this type of agreement as performance errors, rather than a separate agreement strategy, as in (17):

U sali su operisana zglobovi i stopala.
in hall AUX operated

'Joints and feet were operated in the hall.' 
There were also eleven such examples in the oral experiments. Five examples involve a neuter participle form with conjoined feminine and neuter plural nouns, as in (18):
Na petak su pomaknuta
sjednice $i$ vijeća.
to Friday AUX rescheduled meetings $_{F}$ and assemblies
'Meetings and assemblies were rescheduled for Friday.'

Six examples involve a feminine participle form with conjoined neuter and feminine plural nouns, as in (19):
Usobu su naručene jaja i salate.
to room AUX ordered ${ }_{F}$ eggs $_{N}$ and salads ${ }_{F}$
'Eggs and salads were ordered to the room.'

\section{DISCUSSION}

The results of our experiments reveal that the default masculine agreement is more prominent when both conjuncts are not of the same gender, but rather of mixed gender, especially feminine and neuter. In the preverbal written elicitation with [Fem + Neut] conjuncts, one half of participle forms were masculine $(78=50 \%)$; there were 58 neuter forms $(37.18 \%)$ and 20 feminine forms (12.82\%). This clearly demonstrates that participants in our experiment used three strategies of agreement: agreement with the maximal projection - a Boolean Phrase (78 masculine participle forms), agreement with the nearest conjunct (58 neuter participle forms), and agreement with the conjunct which is hierarchically the highest conjunct (20 feminine forms). In the preverbal written elicitation with [Neut + Fem] conjuncts, again the majority of participle forms were masculine (96 $=54.55 \%)$; there were 58 feminine forms $(32.95 \%)$ and 22 neuter forms $(12.50 \%)$. Very similar results were obtained in preverbal oral elicitation with [Neut + Fem] conjuncts: 82 examples $(51.25 \%)$ with masculine agreement, 57 examples $(35.63 \%)$ of feminine agreement, and 21 examples (13.13\%) of agreement with the highest, neuter conjunct. However, in preverbal oral elicitation with [Fem + Neut] conjuncts, there were fewer examples of agreement with the highest, feminine conjunct (only 5 examples $=3.07 \%$ ), with most examples of agreement with the nearest, neuter conjunct $(87$ examples $=$ $53.37 \%$ ), and 71 examples (43.56\%) of default masculine agreement.

The total number of elicited examples, both written and oral, with [Neut $+\mathrm{Fem}]$ and $[\mathrm{Fem}+\mathrm{Neut}]$ conjuncts in preverbal position was 655 . The dominant form of agreement was the default masculine agreement (327 examples, or (roughly) 50\%), then the agreement with the closest conjunct (260 examples, or (roughly) 40\%), and the least represented was the agreement with the highest conjunct (68 examples, or (roughly) $10 \%$ ). The percentage of $10 \%$ is not small, so these examples cannot be treated as performance errors, and therefore we conclude that agreement with the highest conjunct is the third strategy of agreement used by native speakers. This contradicts the claim by Bošković (2009) that highest conjunct agreement in the preverbal position is not possible in BCS. 
Then we investigated possible patterns of participial agreement with [Fem + Neut] and $[\mathrm{Neut}+\mathrm{Fem}]$ conjuncts in the postverbal position. In the postverbal written elicitation with [Fem + Neut] conjuncts, there were no examples of agreement with the furthest, neuter conjunct. There were only four examples $(2.50 \%)$ of default, masculine agreement, and 156 examples $(97.50 \%)$ of nearest, feminine conjunct agreement. In postverbal written elicitation with [Neut + Fem] conjuncts, the majority of examples (172) were again examples of agreement with the nearest, neuter conjunct; there were three examples (1.68\%) of default, masculine agreement, and four examples $(2.23 \%)$ of agreement with the furthest, feminine conjunct. In postverbal oral elicitation with [Fem + Neut] conjuncts, there were 147 examples of agreement with the nearest, feminine conjunct, six examples of default, masculine agreement, and four examples $(2.55 \%)$ of agreement with the furthest, neuter conjunct. In postverbal oral elicitation with [Neut + Fem] conjuncts, there were 162 examples of agreement with the nearest, neuter conjunct, six examples of default, masculine agreement, and six examples $(3.45 \%)$ of agreement with the furthest, feminine conjunct.

The total number of elicited examples, both written and oral, with [Neut + Fem] and $[\mathrm{Fem}+\mathrm{Neut}]$ conjuncts in postverbal position was 670 . The dominant form of agreement was the agreement with the nearest conjunct (637 examples, or (roughly) 95\%), then the default, masculine agreement (19 examples, or (roughly) 3\%), and the least represented was the agreement with the furthest conjunct (14 examples, or (roughly) $2 \%)$. The percentage of $2 \%$ is too small; therefore, these examples should be treated as performance errors rather than a separate agreement strategy (agreement with the furthest conjunct). Thus, our results confirm the claim by Marušič et al. (2015) that a postverbal conjunction does not allow agreement with the second/last/farthest conjunct. The summary of results is presented in the tables in the Appendix.

Finally, we observed the following differences between the results of the written and the oral experiments. With uniform gender conjuncts, there were considerably more default agreement forms in the oral (40 examples) than in the written experiments (6 examples), but only with preverbal subjects. On the other hand, with postverbal subjects, almost the same number of default forms was registered in both the oral (4 examples) and the written experiments (5 examples).

With mixed gender conjuncts in the preverbal position, there were more default agreement forms in the written (735 examples) than in the oral experiments (668 examples). However, there were more examples of closest conjunct agreement in the oral (267 examples) than in the written experiments (200 examples). Finally, there were more examples of highest conjunct agreement in the written (59 examples) than in the oral experiments (42 examples).

With mixed gender conjuncts in the postverbal position, closest conjunct agreement is a dominant form of agreement; it was almost equally represented both in the written (958 examples) and the oral experiments (947 examples). Also, examples of default agreement were almost equally distributed: 23 examples in the written and 26 examples in the oral experiments. 


\section{CONCLUSION}

In this paper, we presented the results of experiments which tested the strategies of subject-predicate agreement in BCS, where the subject consists of conjoined noun phrases. Our experiments confirmed that agreement strategies attested by Marušič et al. (2015) for Slovenian exist in BCS as well. Consequently, BCS, like Slovenian, has three distinct strategies of agreement: 1 . agreement with the maximal projection - a Boolean Phrase (\&P), 2. agreement with the conjunct which is closest to the participle, and 3. agreement with the conjunct which is hierarchically the highest. The results obtained in our experiment justify the claim that Highest Conjunct Agreement (HCA) in contexts with preverbal subjects should be treated as a legitimate agreement strategy in BCS, as opposed to agreement with the furthest conjunct in contexts with postverbal subjects, which we claim to be the result of performance errors. These results are contrary to Bošković's findings (2009), in which he does not acknowledge HCA as a legitimate strategy, however, our results do confirm the findings of Marušič et al. (2015).

\section{References}

AOUN, Joseph/Elabbas BENMAMOUN/Dominique SPORTICHE (1999) "Further Remarks on First Conjunct Agreement." Linguistic Inquiry 30, 669-681.

BENMAMOUN, Elabbas/Archna BHATIA/Maria POLINSKY (2010) "Closest Conjunct Agreement in Head Final Languages." In: J. van Craenenbroeck (ed.), Linguistic Variation Yearbook 2009, 67-88.

BHATT, Rajesh/Martin WALKOW (2013) "Locating Agreement in Grammar: An Argument from Agreement in Conjunctions." Natural Language and Linguistic Theory 31/4, 951-1013.

BOCK, Kathryn/Carol MILLER (1991) "Broken Agreement." Cognitive Psychology 23, 45-93.

BOŠKOVIĆ, Željko (2009) "Unifying First and Last Conjunct Agreement." Natural Language and Linguistic Theory 27, 455- 496.

BOŠKOVIĆ, Željko (2010) "Conjunct-Sensitive Agreement: Serbo-Croatian vs Russian." In: G. Zybatow/P. Dudchuk/S. Minor/E. Pschehotskaya (eds), Formal Studies in Slavic Linguistics: Proceedings of Formal Description of Slavic Languages 7.5. Frankfurt am Main: Peter Lang, 31-48.

CORBETT, Greville (1983a) "Resolution Rules: Agreement in Person, Number and Gender." In: G. Gazdar/E. Klein/G. Pullum (eds), Order, Concord and Constituency. Dordrecht: Foris, 175-214.

CORBETT, Greville (1983b) Hierarchies, Targets, and Controllers: Agreement Patterns in Slavic. London: Croom Helm.

CORBETT, Greville (1991) Gender. Cambridge: Cambridge University Press.

CULICOVER, Peter/Ray JACKENDOFF (2005) Simpler Syntax. Oxford: Oxford University Press. 
DRUMMOND, Alex (2011) IbexFarm. Version 0.2.7. Available http://spellout.net/ ibexfarm

FRANCK, Julie (2011) "Reaching Agreement as a Core Syntactic Process. Commentary on Bock and Middelton 'Reaching Agreement'." Natural Language and Linguistic Theory 29, 1071-1086.

FRANCK, Julie/Glenda LASSI/Ulrich FRAUENFELDER/Luigi RIZZI (2006) "Agreement and Movement: A Syntactic Analysis of Attraction." Cognition 101, $173-216$.

FRANCK, Julie/Ulrich FRAUENFELDER/Luigi RIZZI (2007) “A Syntactic Analysis of Interference in Subject-Verb Agreement." MIT Working Papers in Linguistics 53, 173-190.

MARUŠIČ, Franc/Andrew NEVINS/Amanda SAKSIDA (2007) "Last-Conjunct Agreement in Slovenian.” In: R. Compton/M. Goledzinowska/U. Savchenko (eds), Formal Approaches to Slavic Linguistics 15. Ann Arbor, Mich.: Michigan Slavic Publications, 210-227.

MARUŠIČ, Lanko/Andrew NEVINS/William BADECKER (2015) "The Grammars of Conjunction Agreement in Slovenian." Syntax 18/1, 39-77.

MUNN, Alan (1999) "First Conjunct Agreement: Against a Clausal Analysis." Linguistic Inquiry 30/4, 643-668.

PUŠKAR, Zorica/Andrew MURPHY (2015) "Closest Conjunct Agreement in Serbo-Croatian: A Rule-Ordering Account." In: A. Assmann/S. Bank/D. Georgi/T. Klein/P. Weisser/E. Zimmermann (eds), Topics at Infl. Vol 92 of Linguistische Arbeitsberichte (LAB), Universität Leipzig, 441-482. 


\section{Appendix 1.}

Table 9: Numbers of participle agreement forms with uniform and mixed gender conjuncts

\begin{tabular}{|c|c|c|c|c|c|c|c|c|c|c|c|c|}
\hline & \multicolumn{6}{|c|}{ SV } & \multicolumn{6}{|c|}{ VS } \\
\hline & \multicolumn{3}{|c|}{ WRITTEN } & \multicolumn{3}{|c|}{ ORAL } & \multicolumn{3}{|c|}{ WRITTEN } & \multicolumn{3}{|c|}{ ORAL } \\
\hline & $\mathbf{M}$ & F & $\mathbf{N}$ & M & F & $\mathbf{N}$ & $\mathbf{M}$ & $\mathbf{F}$ & $\mathbf{N}$ & M & $\mathbf{F}$ & $\mathbf{N}$ \\
\hline $\mathbf{M}+\mathbf{M}$ & 179 & 0 & 0 & 178 & 0 & 0 & 180 & 0 & 0 & 180 & 0 & 0 \\
\hline $\mathbf{F}+\mathbf{F}$ & 1 & 179 & 0 & 24 & 151 & 0 & 5 & 153 & 0 & 4 & 173 & 0 \\
\hline $\mathbf{N}+\mathbf{N}$ & 5 & 0 & 174 & 16 & 0 & 164 & 0 & 1 & 176 & 0 & 1 & 175 \\
\hline $\mathbf{M}+\mathbf{F}$ & 150 & 27 & 2 & 128 & 45 & 1 & 177 & 0 & 0 & 179 & 0 & 1 \\
\hline $\mathbf{M}+\mathbf{N}$ & 121 & 0 & 57 & 95 & 1 & 78 & 173 & 0 & 3 & 173 & 0 & 2 \\
\hline $\mathbf{F}+\mathbf{M}$ & 145 & 9 & 1 & 151 & 5 & 2 & 15 & 135 & 2 & 11 & 141 & 0 \\
\hline $\mathbf{F}+\mathbf{N}$ & 78 & 20 & 58 & 71 & 5 & 87 & 4 & 156 & 0 & 6 & 147 & 4 \\
\hline $\mathbf{N}+\mathbf{M}$ & 145 & 0 & 8 & 141 & 1 & 11 & 1 & 0 & 145 & 3 & 0 & 145 \\
\hline $\mathbf{N}+\mathbf{F}$ & 96 & 58 & 22 & 82 & 57 & 21 & 3 & 4 & 172 & 6 & 6 & 162 \\
\hline
\end{tabular}

Table 10: Numbers of performance errors, highest-conjunct agreement, and furthest-conjunct agreement

\begin{tabular}{|l|l|l|l|l|}
\cline { 2 - 5 } \multicolumn{1}{c|}{} & \multicolumn{2}{c|}{ SUBJECT PREVERBAL } & \multicolumn{2}{c|}{ SUBJECT POSTVERBAL } \\
\cline { 2 - 5 } \multicolumn{1}{c|}{} & \multicolumn{1}{c|}{ WRITTEN } & \multicolumn{1}{c|}{ ORAL } & \multicolumn{1}{c|}{ WRITTEN } & \multicolumn{1}{c|}{ ORAL } \\
\hline $\mathrm{M}+\mathrm{M}$ & & & & \\
\hline $\mathrm{F}+\mathrm{F}$ & & & $1 \mathrm{~F}(\mathrm{PE})$ & $1 \mathrm{~F}(\mathrm{PE})$ \\
\hline $\mathrm{N}+\mathrm{N}$ & & $1 \mathrm{~N}(\mathrm{PE})$ & & $1 \mathrm{~N}(\mathrm{PE})$ \\
\hline $\mathrm{M}+\mathrm{F}$ & $2 \mathrm{~N}(\mathrm{PE})$ & $1 \mathrm{~F}(\mathrm{PE})$ & $4 \mathrm{~N}(\mathrm{FC})$ & $1 \mathrm{~F}(\mathrm{PE})$ \\
\hline $\mathrm{M}+\mathrm{N}$ & & $3 \mathrm{~F}(\mathrm{HC}) ; 1 \mathrm{~N}(\mathrm{PE})$ & $2 \mathrm{~N}(\mathrm{PE})$ & $1 \mathrm{MSg}(\mathrm{PE})$ \\
\hline $\mathrm{F}+\mathrm{M}$ & $6 \mathrm{~F}(\mathrm{HC}) ; 1 \mathrm{~N}(\mathrm{PE})$ & & $5 \mathrm{~N}(\mathrm{FC})$ \\
\hline $\mathrm{F}+\mathrm{N}$ & $19 \mathrm{~F}(\mathrm{HC})$ & $4 \mathrm{~F}(\mathrm{HC})$ & & \\
\hline $\mathrm{N}+\mathrm{M}$ & $\begin{array}{l}10 \mathrm{~N}(\mathrm{HC}) ; \\
1 \mathrm{~F}(\mathrm{PE})\end{array}$ & $7 \mathrm{~N}(\mathrm{HC})$ & $1 \mathrm{FSg} ; 1 \mathrm{NSg}(\mathrm{PE})$ & $6 \mathrm{~F}(\mathrm{FC}), 5(\mathrm{PE})$ \\
\hline $\mathrm{N}+\mathrm{F}$ & $22 \mathrm{~N}(\mathrm{HC})$ & $6 \mathrm{~N}(\mathrm{HC})$ & & \\
\hline
\end{tabular}

$\mathrm{PE}=$ performance error

$\mathrm{HC}=$ highest conjunct agreement

$\mathrm{FC}=$ furthest conjunct agreement 
Table 11: Percentages of participle agreement forms with uniform and mixed-gender conjuncts

\begin{tabular}{|c|c|c|c|c|c|c|c|c|c|c|c|c|}
\hline & \multicolumn{6}{|c|}{ Subject preverbal } & \multicolumn{6}{|c|}{ Subject postverbal } \\
\hline & \multicolumn{3}{|c|}{ Written } & \multicolumn{3}{|c|}{ Oral } & \multicolumn{3}{|c|}{ Written } & \multicolumn{3}{|c|}{ Oral } \\
\hline & M & $\mathrm{F}$ & $\mathrm{N}$ & M & $\mathrm{F}$ & $\mathrm{N}$ & M & $\mathrm{F}$ & $\mathrm{N}$ & M & $\mathrm{F}$ & $\mathrm{N}$ \\
\hline $\mathrm{M}+\mathrm{M}$ & $100 \%$ & 0 & 0 & $100 \%$ & 0 & 0 & $100 \%$ & 0 & 0 & $100 \%$ & 0 & 0 \\
\hline $\mathrm{F}+\mathrm{F}$ & 0.56 & 99.44 & 0 & 13.71 & 86.29 & 0 & 3.16 & 96.84 & 0 & 2.26 & 97.74 & 0 \\
\hline $\mathrm{N}+\mathrm{N}$ & 2.79 & 0 & 97.21 & 8.89 & 0 & 91.11 & 0 & 0.56 & 99.44 & 0 & 0.57 & 99.43 \\
\hline $\mathrm{M}+\mathrm{F}$ & 83.80 & 15.08 & 1.12 & 73.56 & 25.86 & 0.57 & $100 \%$ & 0 & 0 & 99.44 & 0 & 0.56 \\
\hline $\mathrm{M}+\mathrm{N}$ & 67.98 & 0 & 32.02 & 54.60 & 0.57 & 44.83 & 98.30 & 0 & 1.70 & 98.86 & 0 & 1.14 \\
\hline $\mathrm{F}+\mathrm{M}$ & 93.55 & 5.81 & 0.65 & 95.57 & 3.16 & 1.27 & 9.87 & 88.82 & 1.32 & 7.24 & 92.76 & 0 \\
\hline $\mathrm{F}+\mathrm{N}$ & 50.00 & 12.82 & 37.18 & 43.56 & 3.07 & 53.37 & 2.50 & 97.50 & 0 & 3.82 & 93.63 & 2.55 \\
\hline $\mathrm{N}+\mathrm{M}$ & 94.77 & 0 & 5.23 & 92.16 & 0.65 & 7.19 & 0.68 & 0 & 99.32 & 2.03 & 0 & 97.97 \\
\hline $\mathrm{N}+\mathrm{F}$ & 54.55 & 32.95 & 12.50 & 51.25 & 35.63 & 13.13 & 1.68 & 2.23 & 96.09 & 3.45 & 3.45 & 93.10 \\
\hline
\end{tabular}

\section{Summary \\ STRATEGIES OF PARTICIPLE AGREEMENT WITH CONJOINED SUBJECTS IN BOSNIAN/CROATIAN/SERBIAN}

In this paper, we demonstrate that Bosnian/Croatian/Serbian (BCS), like Slovenian, has three distinct strategies of subject-predicate agreement when the subject consists of conjoined noun phrases: 1. agreement with the maximal projection - a Boolean Phrase (\&P), 2. agreement with the conjunct which is closest to the participle, and 3. agreement with the conjunct which is hierarchically the highest. In order to test the initial hypothesis that there are three agreement strategies, we conducted a controlled experimental study of the morphosyntax of agreement between conjoined subjects and participles in BCS, which consisted of an oral production experiment and a written production experiment. These experiments revealed a high presence of default agreement and closest conjunct agreement in the language. $50 \%$ of preverbal conjoined phrases elicited the default masculine agreement and $95 \%$ of postverbal conjoined noun phrases elicited the closest conjunct agreement. However, the bulk of the analysis focused on the possibility of treating the highest conjunct agreement (HCA) as a legitimate agreement strategy. $7 \%$ of all of the agreement forms in the subject preverbal (SV) examples demonstrated HCA. These figures increased to $13 \%$ if individual conditions 
were considered. Last conjunct agreement (LCA) for subject postverbal (VS) examples, on the other hand, was only present in $1 \%$ of the examples. For this reason, we classified them as performance errors and refuted LCA as an agreement strategy. These results are contrary to Bošković's findings (2009), in which he does not acknowledge HCA as a legitimate strategy, however, our results do confirm the findings of Marušič et al. (2015).

Keywords: conjunction, closest-conjunct agreement, first-conjunct agreement, experimental syntax

\section{Povzetek \\ STRATEGIJE UJEMANJA DELEŽNIKA S KOORDINIRANIMI OSEBKI V BOSANSKEM/HRVAŠKEM/SRBSKEM JEZIKU}

V članku pokažemo, da ima bosanski/hrvaški/srbski jezik (BHS) tako kot slovenščina tri strategije ujemanja med osebkom in predikatom, ko je osebek koordinirana samostalniška zveza: 1. ujemanje z maksimalno projekcijo - Boolejeva zveza (\&P); 2. ujemanje s koordinirano prvino, ki je bližja deležniku; 3. ujemanje s koordinirano prvino, ki je najvišje v hierarhiji. Da bi preverili podmeno o treh strategijah ujemanja, smo izvedli kontrolirano eksperimentalno študijo oblikoslovno-skladenjskega ujemanja med koordiniranimi osebki in deležniki v BHS, ki je vključevala eksperimenta z govorjenim in pisnim jezikom. Eksperimenta sta pokazala visoko prisotnost privzetega ujemanja in ujemanja z najbližjo koordinirano prvino v osebku. Petdeset odstotkov predglagolskih koordiniranih zvez je pokazalo privzeto ujemanje z moško obliko, petindevetdeset odstotkov zaglagolskih koordiniranih samostalniških zvez pa se je ujemalo po načelu najbližje koordinirane prvine. Analiza je bila v največji meri osredinjena na ustreznost ujemanja s koordinirano prvino, ki je najvišje v hierarhiji (HCA). Slednja se je pojavila v sedmih odstotkih oblik, kjer je bil osebek v predglagolskem položaju. Odstotek naraste na 13, če upoštevamo posamezne pogoje. Ujemanje z zadnjo koordinirano prvino pri zaglagolskih osebkih (LCA) pa je bilo prisotno le v enem odstotku primerov, zato smo jih opredelili kot napake $\mathrm{v}$ rabi jezika in zavrnili LCA kot ustrezno strategijo ujemanja. Rezultati nasprotujejo študiji Boškovića (2009), ki zavrača HCA kot ustrezno strategijo, potrjujejo pa izsledke Marušiča et al. (2015).

Ključne besede: konjunkcija, ujemanje z najbližjo koordinirano prvino, ujemanje $\mathrm{s}$ prvo koordinirano prvino, eksperimentalna skladnja 